\title{
Elements: A Love Song
}

\section{Manya Raman Sundström}

To H.W. Lenstra

Not even this life will perish entirely, laying down my pen at the end of the day, famished, I reach for a slice of dark bread and a cup of tea, still simmering.

Death stops at nothing, but I have this, these words from Euclid, derived from Eudoxus, commensurate, as his units were called, deliberately, not measured.

In these lines he speaks to me, across ages burned to the ground by greed, gunpowder, gusts of wind fed by the malicious storms of misunderstanding. Alexandria burning.

In these lines he sings to me, past the hum of my mother sleeping, the din of students demanding merit, the timbre of requirement rendered mute against a dark, dank silence.

I stand in the wake of this, the tea finished, and the bread now turned to crumbs, a few of which are caught in my freshly ironed cuff, steamed with dignity, sturdy and unruffled.

And I think, whatever forces pull at me, at least I have this-these truths: searing and tender, rugged and binding, love-like and whole, as I was once, in her arms, now dying.

Mathematics is not life, but it fulfills a life, just as my mother will pass and leave me wanting. I turn to Euclid again, as a friend, there, listening.

Department of Science and Mathematics Education Umeå University

90187 Umeå

Sweden

e-mail: manya.sundstrom@matnv.umu.se 